\title{
GAMBARAN TINGKAT PENGETAHUAN TENTANG PENYAKIT REMATIK PADA LANSIA DI PUSKESMAS GAYAMSARI KOTA SEMARANG
}

\author{
M. Jamaluddin ${ }^{1}$, Alfian Haris Nugroho ${ }^{2}$ \\ 1. STIKES Karya Husada Semarang \\ 2. STIKES Karya Husada Semarang \\ Email: afwani_80@yahoo.com
}

\begin{abstract}
ABSTRAK
Angka kejadian rematik pada tahun 2008 yang dilaporkan oleh Organisasi Kesehatan Dunia WHO adalah mencapai $20 \%$ dari penduduk dunia yang telah terserang rematik, dimana 5-10\% adalah mereka yang berusia 520 tahun dan $20 \%$ adalah mereka yang berusia 55 tahun. Dari hasil studi tentang kondisi sosial ekonomi dan kesehatan lanjut usia (Lansia) yang dilaksanakan Komnas Lansia di 10 propinsi tahun 2006, diketahui bahwa penyakit terbanyak yang diderita lansia adalah penyakit sendi $(52,3 \%)$, hipertensi $(38,8 \%)$, anemia $(30,7 \%)$ dan katarak (23\%). Untuk mengetahui tingkat pengetahuan tentang penyakit rematik pada lansia. Jenis penelitian deskriptif dengan desain penelitian menggunakan pendekatan survey. Populasi dalam penelitian ini adalah semua lansia penderita rematik di Puskesmas Gayamsari Kota Semarang sebanyak 75 lansia. Sampel sebanyak 63 lansia dengan teknik sampling menggunakan purposive sampling. Instrumen penelitian adalah kuesioner tingkat pengetahuan tentang penyakit rematik. Analisis data adalah analisis univariat. Umur pada lansia rata-rata adalah 64,67 tahun, jenis kelamin pada lansia mayoritas laki-laki sebanyak 43 responden (68,3\%), pendidikan terakhir pada lansia mayoritas SMP sebanyak 32 responden $(50,8 \%)$ dan lama menderita rematik rata-rata adalah 9,89 tahun. Tingkat pengetahuan tentang penyakit rematik pada lansia di Puskesmas Gayamsari Kota Semarang sebagian adalah pengetahuan baik sebanyak 28 responden $(44,4 \%)$. Pengetahuan cukup sebanyak 27 responden (27\%) dan pengetahuan kurang sebanyak 18 responden $(28,6 \%)$.
\end{abstract}

Kata Kunci : Tingkat pengetahuan, rematik, lansia

Pustaka : $20(2006-2014)$

\section{ABSTRACT \\ THE DESCRIPTION OF KNOWLEDGE OF RHEUMATIC DISEASES IN ELDERLY IN SEMARANG CITY HEALTH GAYAMSARI}

\begin{abstract}
The incidence of arthritis in 2008 reported by the World Health Organization WHO is to achieve $20 \%$ of the world population that has been attacked by rheumatism, which is 5-10\% of those aged 5-20 years and $20 \%$ were those aged 55 years. From the results of studies on the socio-economic and health conditions of elderly (Elderly) held the National Commission on the Elderly in 10 provinces in 2006, it is known that most diseases suffered by the elderly is a joint disease (52.3\%), hypertension (38.8\%), anemia $(30.7 \%)$ and cataract $(23 \%)$. To determine the level of knowledge about rheumatic diseases in the elderly. Descriptive research with survey research design approach. The population in this study were all elderly patients with rheumatoid arthritis in Puskesmas Gayamsari Semarang as many as 75 elderly. A sample of 63 elderly by sampling using purposive sampling technique. The research instrument was a questionnaire level of knowledge about rheumatic diseases. The data analysis is univariate analysis. Age of the elderly average is 64.67 years, the majority gender in elderly men as much as 43 respondents $(68.3 \%)$, the latest education of the elderly majority of SMP were 32 respondents $(50.8 \%)$ and long-suffering rheumatism average -rata is 9.89 years. The level of knowledge about rheumatic diseases in the elderly in Puskesmas Gayamsari Semarang portion is good knowledge of as many as 28 respondents $(44.4 \%)$. Knowledge quite as much as 27 respondents $(27 \%)$ and lack of knowledge as much as 18 respondents $(28.6 \%)$.
\end{abstract}

Jurnal SMART Keperawatan Sekolah Tinggi Ilmu Kesehatan (STIKes) Karya Husada

Semarang www.stikesyahoedsmg.ac.id/ojs/index.php/sjkp(perawat) 
Keywords : The level of knowledge, rheumatism, elderly

Book : $20(2006-2014)$

\section{Pendahuluan}

Lanjut usia merupakan bagian dari proses tumbuh kembang. Manusia tidak secara tiba-tiba menjadi tua, tetapi berkembang dari bayi, anak-anak, dewasa, dan akhirnya menjadi tua. Usia tua merupakan periode penutup dalam rentang hidup seseorang, yaitu suatu periode dimana seorang telah "beranjak jauh" dari periode terdahulu yang lebih menyenangkan atau beranjak dari waktu yang penuh dengan manfaat. Seseorang sudah beranjak jauh dari periode terdahulu, melihat masa lalunya dan cenderung ingin hidup (Monks \& Knoers, 2006).

Rematik merupakan kondisi yang disertai nyeri dan kaku sendi pada sistem muskuloskeletal. Penyakit rematik yang sering juga disebut arthritis (radang sendi) dan dianggap sebagai satu keadaan, mempunyai lebih dari 100 tipe kelainan yang berbeda. Penyakit ini terutama mengenai otot-otot skelet, tulang, ligamentum, tendon dan persendian baik pada laki-laki maupun wanita dengan segala usia, tetapi kelompok lansia lebih banyak terkena serangan rematik (Smeltzer \& Bare, 2008).

Penyakit ini menyebabkan banyak keluhan yang diderita oleh pasien diantaranya nyeri yang dapat menyerang lutut, pergelangan tangan, kaki, dan di berbagai persendian lainnya. Keluhan yang disebabkan penyakit ini sering menyebabkan kualitas hidup pasien menjadi sangat menurun. Selain menurunkan kualitas hidup, rematik juga meningkatkan beban sosial ekonomi bagi para penderitannya (Wenni, 2012).

Menurut Subagiyo (2010) terdapat lebih dari 355 juta orang di dunia ternyata menderita penyakit rematik. Itu berarti, setiap enam orang di dunia ini satu di antaranya adalah penyandang reumatik. Namun, sayangnya pengetahuan tentang penyakit reumatik belum tersebar secara luas. Sehingga banyak mitos yang keliru beredar di tengah masyarakat yang justru menghambat penanganan penyakit itu. Di Indonesia pada tahun 2004 angka kejadian penyakit rematik mencapai 2 juta dengan angka perbandingan pasien wanita tiga kali lipatnya dari laki-laki menderita penyakit reumatik.

Angka kejadian rematik pada tahun 2008 yang dilaporkan oleh Organisasi Kesehatan Dunia WHO adalah mencapai $20 \%$ dari penduduk dunia yang telah terserang rematik, dimana 5-10\% adalah mereka yang berusia 5-20 tahun dan 20\% adalah mereka yang berusia 55 tahun (Wiyono, 2010). Dari hasil studi tentang kondisi sosial ekonomi dan kesehatan Jurnal SMART Keperawatan Sekolah Tinggi Ilmu Kesehatan (STIKes) Karya Husada Semarang www.stikesyahoedsmg.ac.id/ojs/index.php/sjkp(perawat) 
lanjut usia (Lansia) yang dilaksanakan Komnas Lansia di 10 propinsi tahun 2006, diketahui bahwa penyakit terbanyak yang diderita lansia adalah penyakit sendi (52,3\%), hipertensi $(38,8 \%)$, anemia $(30,7 \%)$ dan katarak $(23 \%)$. Penyakit-penyakit tersebut merupakan penyebab utama disabilitas pada lansia (Roehadi, 2008).

Jumlah penduduk usia lanjut dunia diperkirakan ada 500 juta dengan usia rata-rata 60 tahun dan diperkirakan pada tahun 2025 akan mencapai 1,2 milyar. Jumlah penduduk lanjut usia yang berumur > 60 tahun pada tahun 2014 di Indonesia sebanyak 18. 861.820 jiwa, dengan laki-laki sebanyak 8.666.060 jiwa, dan perempuan 10.195.760 jiwa. Jumlah penduduk usia > 60 tahun di Jawa Tengah sebanyak 2.815.921, dengan laki-laki sebanyak 1.322.543 jiwa dan perempuan sebanyak 1.493. 378 jiwa (Profil Kesehatan Indonesia, 2014).

Berdasarkan hasil penelitian terakhir dari Zeng (2008), prevalensi nyeri rematik di Indonesia mencapai $23,6 \%$ hingga 31,3\%. Angka ini menunjukkan bahwa rasa nyeri akibat reumatik sudah cukup mengganggu aktivitas masyarakat Indonesia, terutama mereka yang memiliki aktivitas. Dari segi pelayanan kesehatan bertambahnya jumlah lansia dapat diartikan bertambah pula permasalahan kesehatan oleh karena pada kelompok ini terjadi berbagai perubahan fungsi fisiologik. Berdasarkan penelitian yang dilakukan di Jakarta Barat oleh Kurniawan pada Juli 2012 didapatkan penyakit rematik menempati urutan pertama pada lansia $(64,8 \%)$, kemudian penyakit jantung $(20,4 \%)$, dan penyakit diabetes melitus $(16,9 \%)$.

Penelitian Yuliati (2011), hasil penelitian menunjukkan bahwa pengetahuan responden tentang pengobatan rematik dengan air rebusan jahe baik sebanyak 55,8\%, pengetahuan cukup sebanyak 2,3\% dan pengetahuan kurang sebanyak 41,9\%.

Berdasarkan uraian diatas, maka peneliti tertarik untuk melakukan penelitian mengenai "Gambaran tingkat pengetahuan tentang penyakit rematik pada lansia di Puskesmas Gayamsari Kota Semarang”.

\section{Tinjauan Teoritis}

\section{A. Lanjut Usia (lansia)}

Undang-undang RI No.13 tahun 1998 tentang kesejahteraan lanjut usia yang berbunyi lanjut usia adalah seseorang yang mencapai usia 60 tahun keatas. Lanjut usia merupakan suatu proses biologis yang tidak dapat dihindarkan, yang akan dialami oleh setiap orang. Menua adalah suatu proses menghilangnya secara perlahan kemampuan 
jaringan untuk memperbaiki diri atau mengganti dan mempertahankan struktur dan fungsi secara normal, ketahanan terhadap injury termasuk adanya infeksi (Nugroho, 2008).

Lanjut usia merupakan suatu proses biologis yang tidak dapat dihindarkan, yang akan dialami oleh setiap orang. Menua adalah suatu proses menghilangnya secara perlahan kemampuan jaringan untuk memperbaiki diri atau mengganti dan mempertahankan struktur dan fungsi secara normal, ketahanan terhadap injury termasuk adanya infeksi. Proses menua sudah mulai berlangsung sejak seseorang mencapai dewasa, misalnya dengan terjadinya kehilangan jaringan pada otot, susunan syaraf dan jaringan lain sehingga tubuh "mati" sedikit demi sedikit. Pada setiap orang, fungsi fisiologis alat tubuhnya sangat berbeda, baik dalam hal pencapaian puncak maupun saat menurunnya. Namun umumnya fungsi fisiologis tubuh mencapai puncaknya pada umur 20-30 tahun (Mubarak, 2006).

\section{B. Rematik}

1. Pengertian Rematik

Rematik adalah orang yang menderita rheumatism (Encok), arthritis (radang sendi) ada 3 jenis arthritis yang paling sering diderita adalah osteoarthritis, arthritis goud, dan rheumatoid artirtis yang menyebabkan pembengkakan benjolan pada sendi atau radang pada sendi secara serentak (Utomo, 2008). Penyakit rematik meliputi cakupan luas dari penyakit yang dikarakteristikkan oleh kecenderungan untuk mengefek tulang, sendi, dan jaringan lunak (Soumya, 2011).

2. Jenis-jenis Rematik

Rematik dapat dikelompokan dalam beberapa golongan yaitu :

\section{a. Osteoartritis}

Penyakit ini merupakan penyakit kerusakan tulang rawan sendi yang berkembang lambat dan berhubungan dengan usia lanjut. Secara klinis ditandai dengan nyeri, deformitas, pembesaran sendi, dan hambatan gerak pada sendi-sendi tangan dan sendi besar yang menanggung beban.

b. Artritis Rematoid

Artritis rematoid adalah suatu penyakit inflamasi sistemik kronik dengan manifestasi utama poliartritis progresif dan melibatkan seluruh organ tubuh. Terlibatnya sendi pada pasien artritis rematoid terjadi setelah penyakit ini 
berkembang lebih lanjut sesuai dengan sifat progresifitasnya. Pasien dapat juga menunjukkan gejala berupa kelemahan umum cepat lelah.

c. Olimialgia Reumatik

Penyakit ini merupakan suatu sindrom yang terdiri dari rasa nyeri dan kekakuan yang terutama mengenai otot ekstremitas proksimal, leher, bahu dan panggul. Terutama mengenai usia pertengahan atau usia lanjut sekitar 50 tahun ke atas.

d. Artritis Gout (Pirai)

Artritis gout adalah suatu sindrom klinik yang mempunyai gambaran khusus, yaitu artritis akut. Artritis gout lebih banyak terdapat pada pria dari pada wanita. Pada pria sering mengenai usia pertengahan, sedangkan pada wanita biasanya mendekati masa menopause.

\section{Pengetahuan (knowledge)}

1. Pengertian Pengetahuan

Notoatmodjo (2010), pengetahuan merupakan hasil dari tahu, dan ini terjadi setelah orang melakukan penginderaan terhadap suatu objek tertentu. Penginderaan terjadi melalui panca indera manusia, yakni indera penglihatan, pendengaran, penciuman, rasa dan raba. Pengetahuan atau kognitif merupakan domain yang sangat penting dalam membentuk tindakan seseorang (overt behavior).

2. Tingkatan pengetahuan

Notoatmodjo (2010), pengetahuan tercakup dalam domain kognitif mempunyai 6 tingkatan yaitu :

a. Tahu (know)

Tahu diartikan sebagai mengingat suatu materi yang telah dipelajari sebelumnya.

b. Memahami (comprehension)

Suatu kemampuan untuk menjelaskan secara benar tentang obyek yang diketahui dan dapat menginterpretasikan materi tersebut secara benar.

c. Aplikasi (application)

Kemampuan untuk menggunakan materi yang telah dipelajari pada situasi atau kondisi real (sebenarnya).

d. Analisis (analysis) 
Suatu kemampuan untuk menjabarkan materi atau suatu subyek ke dalam komponen-komponen, tetapi masih di dalam suatu struktur organisasi dan masih ada kaitannya satu sama lain.

e. Sintesis (synthetis)

Sintesis yaitu menunjukkan pada suatu kemampuan untuk meletakkan atau menghubungkan bagian-bagian didalam suatu kemampuan untuk menyusun formula baru.

f. Evaluasi (evaluation)

Evaluasi ini berkaitan dengan kemampuan untuk melakukan penilaian terhadap suatu obyek atau materi.

\section{Metode Penelitian}

\section{A. Jenis dan Desain Penelitian}

Penelitian ini menggunakan jenis penelitian kuantitatif dengan pendekatan deskriptif. Penelitian ini untuk mengetahui tingkat pengetahuan tentang penyakit rematik pada lansia.

Desain dalam penelitian ini menggunakan pendekatan survei. Pengumpulan data kuesioner tingkat pengetahuan tentang penyakit rematik pada lansia dilakukan dalam waktu bersamaan.

\section{B. Waktu dan Tempat Penelitian}

1. Waktu Penelitian

Waktu penelitian dimulai dari penyusunan proposal sampai dengan turunnya penelitian yaitu dari bulan November 2015 sampai dengan Juni 2016.

2. Tempat Penelitian

Tempat penelitian dilakukan di Puskesmas Gayamsari Kota Semarang.

\section{Populasi, Sampel dan Teknik Sampling}

Populasi dalam penelitian ini adalah semua lansia penderita rematik di Puskesmas Gayamsari Kota Semarang sebanyak 75 lansia. Sampel dalam penelitian sebanyak 63 responden. Teknik pengambilan sampel yang digunakan adalah purposive sampling. 


\section{Analisa Data}

Analisa data dalam penelitian ini menggunakan bentuk analisis univariate yang dilakukan tiap variabel dari hasil penelitian. Setelah dilakukan pengumpulan data kemudian data dianalisa menggunakan statistik deskriptif untuk mendapatkan dalam bentuk tendensi sentral (mean, standar deviasi, minimum dan maksimum) pada variabel umur dan lama menderita rematik. Sedangkan jenis kelamin, pendidikan dan tingkat pengetahuan tentang penyakit rematik ditampilkan dalam bentuk distribusi frekuensi dan persentase (\%) dari masing-masing variabel dengan menggunakan rumus (Machfoed, 2007)

\section{Hasil Penelitian}

\section{A. Hasil}

1. Karakteristik Responden

a. Umur pada lansia di Puskesmas Gayamsari Kota Semarang

Tabel 4.1 Distribusi responden berdasarkan umur pada lansia di Puskesmas Gayamsari Kota Semarang

\begin{tabular}{rlcccc}
\hline Variabel & N & Mean & SD & Min & Max \\
\hline Umur pada lansia & 63 & 64,67 & 3,02 & 60 & 70 \\
\hline
\end{tabular}

b. Jenis kelamin pada lansia di Puskesmas Gayamsari Kota Semarang

Tabel 4.2 Distribusi frekuensi responden berdasarkan jenis kelamin pada lansia di Puskesmas Gayamsari Kota Semarang

\begin{tabular}{ccc}
\hline $\begin{array}{c}\text { Jenis kelamin } \\
\text { pada lansia }\end{array}$ & Frekuensi & Persentase \\
\hline Laki-laki & 43 & 68,3 \\
Perempuan & 20 & 31,7 \\
\hline Total & $\mathbf{6 3}$ & $\mathbf{1 0 0}$ \\
\hline
\end{tabular}

c. Pendidikan terakhir pada lansia di Puskesmas Gayamsari Kota Semarang

Tabel 4.3 Distribusi frekuensi responden berdasarkan pendidikan terakhir pada lansia di Puskesmas Gayamsari Kota Semarang

\begin{tabular}{ccc}
$\begin{array}{c}\text { Pendidikan terakhir } \\
\text { pada lansia }\end{array}$ & Frekuensi & Persentase \\
\hline
\end{tabular}




\begin{tabular}{ccc}
\hline SD & 3 & 4,8 \\
SMP & 32 & 50,8 \\
SMA & 24 & 38,1 \\
D III / S 1 & 4 & 6,3 \\
\hline Total & $\mathbf{6 3}$ & $\mathbf{1 0 0}$ \\
\hline
\end{tabular}

d. Lama menderita rematik di Puskesmas Gayamsari Kota Semarang

Tabel 4.4 Distribusi responden berdasarkan lama menderita rematik pada lansia di Puskesmas Gayamsari Kota Semarang

\begin{tabular}{cccccc}
\hline Variabel & N & Mean & SD & Min & Max \\
\hline Lama menderita rematik & 63 & 9,89 & 2,32 & 7 & 15 \\
\hline
\end{tabular}

2. Tingkat pengetahuan tentang penyakit rematik pada lansia di Puskesmas Gayamsari Kota Semarang

Tabel 4.5 Distribusi frekuensi responden berdasarkan tingkat pengetahuan tentang penyakit rematik pada lansia di Puskesmas Gayamsari Kota Semarang

\begin{tabular}{ccc}
\hline $\begin{array}{c}\text { Tingkat pengetahuan tentang } \\
\text { penyakit rematik }\end{array}$ & Frekuensi & Persentase \\
\hline Pengetahuan kurang & 18 & 28,6 \\
Pengetahuan cukup & 27 & 27 \\
Pengetahuan baik & 28 & 44,4 \\
\hline Total & $\mathbf{6 3}$ & $\mathbf{1 0 0}$ \\
\hline
\end{tabular}

\section{Pembahasan}

3. Karakteristik Responden

a. Umur pada lansia di Puskesmas Gayamsari Kota Semarang

Hasil penelitian dapat diketahui umur pada lansia di Puskesmas Gayamsari Kota Semarang rata-rata adalah 64,67 tahun dengan standard deviasi 3,02. Umur merupakan faktor resiko untuk timbulnya rematik. Prevalensi dan beratnya penyakit rematik semakin meningkat dengan bertambahnya umur. Penyakit rematik hampir tak pernah pada anak-anak, jarang pada umur dibawah 40 tahun dan sering pada umur diatas 60 tahun.

Menurut Albadroe (2007), dari semua faktor resiko terjadinya rematik bahwa faktor yang terkuat adalah faktor ketuaan. Prevalensi dan beratnya rematik akan semakin meningkat seiring dengan bertambahnya umur, artinya semakin tua seseorang maka resiko terjadinya arthritis rheumatoid juga akan semakin meningkat. 
Menurut Nugroho (2010), umumnya setelah seseorang memasuki tahap lansia maka akan mengalami penurunan fungsi kognitif (proses belajar, persepsi, pemahaman, pengertian, dan lain-lain) dan psikomotor (gerakan, tindakan, koordinasi). Julianti (2008), berpendapat bahwa beberapa kemampuan intelektual menurun, sedangkan kemampuan lainnya tidak. Kecerdasan yang mengkristal (crystallized intelligence, yaitu sekumpulan informasi dan kemampuankemampuan verbal yang dimiliki individu) meningkat, seiring dengan peningkatan usia, sedangkan kecerdasan yang mengalir (fluid intelligence, yaitu kemampuan seseorang untuk berpikir abstrak) menurun secara pasti sejak masa dewasa madya.

Julianti (2008), dari hasil penelitianya bahwa tidak ditemukan penurunan intelektual pada masa dewasa, setidaknya sampai usia 70 tahun. Penurunan di dalam kemampuan-kemampuan mental rata-rata dimulai pada usia 74 tahun. Penelitian lain membuktikan bahwa orang-orang dewasa lanjut kurang mampu mengeluarkan kembali informasi yang telah disimpan dalam ingatannya.

Didukung penelitian Prianto (2010), hasil penelitian menunjukkan bahwa umur penderita rematik sebagian besar umur 60 tahun keatas tahun sebanyak 36 responden $(58,5 \%)$.

b. Jenis kelamin pada lansia di Puskesmas Gayamsari Kota Semarang

Hasil penelitian dapat diketahui bahwa jenis kelamin pada lansia di Puskesmas Gayamsari Kota Semarang adalah mayoritas laki-laki sebanyak 43 responden $(68,3 \%)$ dan perempuan sebanyak 20 responden $(31,7 \%)$.

Wanita lebih sering terkena osteoartritis lutut dan sendi, dan lelaki lebih sering terkena osteoartritis paha, pergelangan tangan dan leher. Secara keeluruhan dibawah 45 tahun frekuensi rematik kurang lebih sama pada laki dan wanita tetapi diatas 50 tahun frekuensi oeteoartritis lebih banyak pada wanita dari pada pria hal ini menunjukkan adanya peran hormonal pada patogenesis rematik.

Didukung penelitian Bima (2011), hasil penelitian menunjukkan bahwa jenis kelamin pada lansia penderita rematik mayoritas adalah laki-laki sebanyak 39 responden $(65,7 \%)$.

c. Pendidikan terakhir pada lansia di Puskesmas Gayamsari Kota Semarang 
Hasil penelitian dapat diketahui bahwa pendidikan terakhir pada lansia di Puskesmas Gayamsari Kota Semarang adalah mayoritas SMP sebanyak 32 responden $(50,8 \%)$. Semakin tinggi pendidikan yang merupakan salah satu faktor yang mempengaruhi persepsi seseorang untuk lebih mudah menerima pengetahuan baru dan semakin tinggi pengetahuan seseorang akan semakin baik pengetahuannya.

Hendra (2008), mengatakan bahwa tingkat pendidikan turut menentukan mudah tidaknya seseorang menyerap dan memahami suatu pengetahuan yang mereka peroleh, pada umumnya semakin tinggi pendidikan seseorang makin baik pengetahuannya dan makin mudah pula untuk menerima informasi.

d. Lama menderita rematik di Puskesmas Gayamsari Kota Semarang

Hasil penelitian dapat diketahui bahwa lama menderita rematik pada lansia di Puskesmas Gayamsari Kota Semarang rata-rata adalah 9,89 tahun dengan standard deviasi 2,32. Lama menderita rematik paling rendah adalah 7 tahun dan tertinggi adalah 15 tahun. Lanjut usia dengan riwayat rematik yang lama akan berpengaruh terhadap proses masuknya pengetahuan ke dalam individu. Interaksi timbal balik di lingkungan tempat tinggal lansia itu sendiri akan menimbulkan sikap sosial dalam bergaul sehingga akan direspon sebagai pengetahuan oleh lansia

Pengalaman dalam pengobatan rematik juga mempengaruhi pengetahuan responden sehingga semakin lama lansia menderita rematik, maka pengetahuanya akan semakin baik.

4. Tingkat pengetahuan tentang penyakit rematik pada lansia di Puskesmas Gayamsari Kota Semarang

Hasil penelitian dapat diketahui bahwa tingkat pengetahuan tentang penyakit rematik pada lansia di Puskesmas Gayamsari Kota Semarang sebagian adalah pengetahuan baik sebanyak 28 responden (44,4\%). Pengetahuan yang baik pada responden dikarenakan faktor umur. Umur berpengaruh terhadap pengetahuan lansia sesuai dengan pendapat Hendra (2008), bahwa semakin tua umur seseorang maka proses-proses perkembangan mentalnya akan membaik dan sangat berpengaruh pada pengetahuan yang diperolehnya. 
Menurut Notoatmodjo (2010), Tingkat pendidikan seseorang akan berpengaruh dalam memberi respon yang datang dari luar. Orang yang berpendidikan tinggi akan memberi respon yang lebih rasional terhadap informasi yang datang dan akan berfikir sejauh mana keuntungan yang mungkin akan mereka peroleh dari gagasan tersebut.

Pengetahuan baik juga dikarenakan lansia mendapat informasi tentang penyakit rematik. Di wilayang Gayamsari terdapat posyandu lansia dimana di posyandu tersebut ada kegiatan penyuluhan kesehatan. Menurut Notoatmodjo (2007), bahwa sumber informasi yang diperoleh dari berbagai sumber maka seseorang cenderung mempunyai pengetahuan yang lebih luas. Informasi akan memberikan pengaruh pada pengetahuan seseorang, meskipun seseorang memiliki pendidikan yang rendah tetapi jika mendapatkan informasi yang baik dari berbagai media informasi (TV, radio, majalah, penyuluhan, dan lain-lain) akan meningkatkan pengetahuan seseorang.

Sumber informasi sangat mempengaruhi pengetahuan seseorang baik pemberi informasi maupun penerima (lanjut usia), tetapi tergantung dari minat lansia untuk mencari informasi dari berbagai sumber baik dari majalah atau buku kesehatan, leaflet, koran, mengikuti perkumpulan atau penyuluhan tentang kesehatan. Pemberi informasi khususnya petugas kesehatan dalam menyampaikan informasi mengenai kesehatan akan mempengaruhi pengetahuan dan perubahan yang diterima oleh lanjut usia apakah hal ini baik atau buruk untuk dilakukan (Zainudin, 2009).

Didukung penelitian Aksianto (2009), hasil penelitian menunjukkan bahwa tingkat pengetahuan tentang penyakit rematik pada lansia sebagian adalah pengetahuan baik sebanyak 25 responden $(58,5 \%)$.

\section{Kesimpulan}

Umur pada lansia rata-rata adalah 64,67 tahun, jenis kelamin pada lansia mayoritas laki-laki sebanyak 43 responden $(68,3 \%)$, pendidikan terakhir pada lansia mayoritas SMP sebanyak 32 responden $(50,8 \%)$ dan lama menderita rematik rata-rata adalah 9,89 tahun. Tingkat pengetahuan tentang penyakit rematik pada lansia di Puskesmas Gayamsari Kota Semarang sebagian adalah pengetahuan baik sebanyak 28 responden $(44,4 \%)$. Pengetahuan cukup sebanyak 27 responden (27\%) dan pengetahuan kurang sebanyak 18 responden $(28,6 \%)$. 


\section{Saran}

1. Bagi Pasien

Bagi pasien hendaknya meningkatkan pengetahuan mereka tentang pengertian, penyebab, tanda dan gejala, penatalaksanaan dan pencegahan kekambuhan penyakit reumatik. Pasien dapat meningkatkan pengetahuannya dengan cara bertanya kepada orang yang memiliki pengalaman dalam pencegahan penyakit reumatik ataupun kepada petugas kesehatan yang ada di wilayah mereka.

2. Bagi Puskesmas Gayamsari Kota Semarang

Diharapkan bagi tenaga kesehatan memberikan pendidikan kesehatan secara kontinue kepada lansia khusunya tentang penyakit rematik, agar pengetahuan menjadi lebih baik.

3. Bagi Peneliti Selanjutnya

Diharapkan dalam penelitian lebih lanjut dengan pengembangan variabel penelitian dan jumlah populasi yang lebih banyak sehingga akan lebih diperoleh hasil yang lebih baik.

\section{Daftar Pustaka}

Amin, S. 2010. Gambaran tingkat pengetahuan tentang penyakit rematik pada lansia di Puskesmas Guntur Kabupaten Demak. KTI tidak dipublikasikan.

Anwar, S. 2014. Pengetahuan lansia dengan arthritis rheumatoid dalam mengaplikasikan senam rematik di UPT pelayanan sosial lanjut usia dan balita Wilayah Medan Binjai Tahun 2014. KTI tidak dipublikasikan.

Azizah, L. 2011. Keperawatan Lanjut Usia. Edisi Pertama. Yogyakarta : Graha Ilmu.

Darmojo, R.B \& Martono, H.H. 2006. Geriatri (Ilmu Kesehatan Usia lanjut). Jakarta : Balai Penerbit FKUI.

Machfoedz, I. 2007. Statistika Deskriptif : Bidang Kesehatan, Keperawatan dan Kebidanan (Bio Statistik). Yogyakarta : Fitramaya.

Mubarak. 2006. Ilmu Kesehatan dan Masyarakat: Teori dan Aplikasi. Jakarta : Penerbit Salemba Medika.

Notoatmodjo, S. 2010. Pendidikan dan perilaku kesehatan. Jakarta : PT Rineka Cipta. 
Nugroho, W. 2008. Keperawatan Gerontik. Jakarta : Penerbit Buku Kedokteran EGC.

Profil Kesehatan Indonesia. 2014. Profil Kesehatan Indonesia. Jakarta.

Purnomo, J. 2010. Hubungan antara tingkat pengetahuan dengan sikap lansia dalam mengatasi kekambuhan penyakit reumatik di Posyandu Lansia Kelurahan Karangasem Kecamatan Laweyan Kota Surakarta. Skripsi tidak dipublikasikan.

Sugiyono. 2011. Metode Penelitian Pendidikan. Bandung : CV Alfabeta.

Sukmadinata, S.N. 2010. Landasan Psikologi Proses Pendidikan. Bandung: PT Remaja Rosdakarya Bandung.

Surajiyo. 2010. Filsafat Ilmu dan Perkembangannya di Indonesia. Jakarta : Bumi Aksara.

Wawan, A \& Dewi, M. 2010. Teori dan Pengukuran Pengetahuan, Sikap, dan Perilaku Manusia. Yogyakarta : Nuha Medika.

Yuliati. 2011. Gambaran pengetahuan keluarga tentang pengobatan rematik dengan air rebusan jahe di Kelurahan Meranti Pandak Wilayah Kerja Puskesmas Rumbai. KTI tidak dipublikasikan. 